\title{
Nilai Estetika Lokal dan Nilai Ekonomi Lokal Dalam Pengelolaan Destinasi Pariwisata di Bali Utara
}

\author{
Dewa Ayu Diyah Sri Widari ${ }^{*}$, Dewa Putu Oka Prasiasa ${ }^{2}$ \\ ${ }^{1}$ Prodi D3 Perhotelan, Akademi Pariwisata Denpasar, Denpasar \\ Jl. Tukad Balian No. 15 Niti Mandala Renon, Denpasar, Bali, Indonesia 80226 \\ ${ }^{2}$ Prodi S1 Manajemen, STIMI Handayani, Denpasar \\ Jl. Tukad Banyusari No. 17B, Denpasar, Bali, Indonesia 80225 \\ dewaayusriwidari@gmail.com ${ }^{1 *}$
}

Penelitian ini bertujuan menemukan nilai estetika lokal dan nilai ekonomi lokal sebagai dampak dari interaksi nilai lokal dan nilai global dalam pengelolaan destinasi pariwisata di Bali Utara. Adapun metode yang dipergunakan adalah metode tinjauan pustaka berdasarkan analisis deskriptif kualitatif. Temuan dari penelitian ini adalah unsur lokalitas dalam pengelolaan destinasi pariwisata di Bali Utara terbentuk dari perwujudan nilai estetika dan nilai ekonomi lokal yang diyakini sebagai kearifan lokal masyarakat, dan kedua nilai ini bersifat dominan. Ni1ai-nilai yang dibawa oleh wisatawan dapat berimplikasi positif (tonic) dan negatif (toxic), sekaligus menjadi penggerak perubaan nilai bagi masyarakat lokal. Kontribusi nilai estetika dan nilai ekonomi lokal terhadap nilai-nilai yang dibawa oleh wisatawan belum optimal dalam pengelolaan destinasi pariwisata di Bali Utara.

Kata kunci: Estetika Lokal, Ekonomi Lokal, Nilai, Destinasi Pariwisata, Bali Utara

\section{Local Aesthetic Values and Local Economic Values in the Management of Tourism Destinations in North Bali}

This study aims to find local aesthetic values and local economic values as a result of the interaction of local values and global values in the management of tourism destinations in North Bali. The method used is a literature review method based on qualitative descriptive analysis. The findings of this study are that the element of locality in the management of tourism destinations in North Bali is formed from the embodiment of aesthetic values and local economic values which are believed to be local wisdom of the community, and these two values are dominant. The values brought by tourists can have positive (tonic) and negative (toxic) implications, as well as being a driver of value change for local communities. The contribution of aesthetic value and local economic value to the values brought by tourists has not been optimal in managing tourism destinations in North Bali.

Keywords: Local Aesthetics, Local Economy, Values, Tourism Destinations, North Bali

Received: November 3, 2021; Accepted January 20, 2022; Published February 8, 2022

https://doi.org/10.31091/mudra.v37i1.1883

(C) 2021 The Author(s). Published by Pusat Penerbitan LP2MPP Institut Seni Indonesia Denpasar.

This is an open-access article under the CC BY-NC-SA license 


\section{PENDAHULUAN}

Globalisasi berdampak pada percepatan akses, informasi, dan interaksi tanpa batas. Globalisasi juga memungkinkan terjadinya dinamisasi terhadap tatanan nilai di masyarakat. Selain itu globalisasi juga dapat meningkatkan kesadaran dan penghargaan terhadap lokalitas. Peningkatan kesadaran akan lokalitas muncul karena adanya kesadaran kritis akan terjadinya disorientasi terhadap pengelolaan sumber daya ekonomi, budaya dan lingkungan.

Pengelolaan destinasi pariwisata merupakan salah satu faktor dalam menentukan kinerja dan kualitas pariwisata. Oleh karena itu setiap destinasi pariwisata memerlukan pendekatan pengelolaan destinasi dengan menerapkan prinsif pembangunan pariwisata berkelanjutan. Pengelolaan destinasi pariwisata menurut Page (2007) serta Carter dan Fabricus (2006) mengacu pada nilai lokal untuk keberlanjutan sumber daya dan kapasitas masyarakat di destinasi pariwisata, dengan tujuan untuk meningkatkan kualitas pengalaman wisata.

Kondisi yang terjadi dalam pembangunan di Bali pada umumnya dan di Bali Utara pada khususnya di sektor pariwisata, bahwa kepariwisataan lebih menonjolkan aspek ekonomi dan semata-mata tujuannya adalah untuk memenuhi target kepentingan dan kepuasan wisatawan. Aspek-aspek yang terkait dengan lokalitas kurang mendapat perhatian, padahal untuk mewujudkan pengelolaan destinasi pariwisata yang baik, penerapan prinsip pembangunan berkelanjutan, berbasis masyarakat menurut Page (2007) dan Bornhorst et.al (2010) sangat perlu memperhatikan dan mengadopsi unsurunsur lokalitas.

Pada kenyataannya, fenomena yang muncul terkait implementasi unsur-unsur lokalitas dalam pengelolaan destinasi pariwisata di Bali Utara (dari Timur yaitu kawasan Air Sanih sampai ke Barat yaitu kawasan Pemuteran) antara lain nilai lokal yang digunakan dan dipraktikkan dalam pengelolaan destinasi pariwisata kurang sepenuhnya menggambarkan identitas masyarakat Bali Utara; nilai yang bersifat ekonomi lebih dominan dari nilai estetika; dan intepretasi nilai yang terjadi lebih ditentukan oleh pemilik modal, atau yang berkuasa secara ekonomi, sehingga rasa memiliki dan rasa bertanggungjawab untuk berperan serta menjaga dan melestarikan nilai-nilai lokal dalam pengelolaan destinasi pariwisata menjadi semakin berkurang.

Penelitian ini berusaha untuk menemukan nilai estetika lokal dan nilai ekonomi lokal sebagai dampak dari interaksi nilai lokal dan nilai global dalam pengelolaan destinasi pariwisata di Bali Utara. Selama ini parameter ekonomi yang diterapkan untuk mengukur keberhasilan pariwisata memiliki keterbatasan karena tidak mampu mengungkap dimensi penting lainnya dari pariwisata yang potensial; dan penggunaan parameter ekonomi, sosial, budaya, dan ekologi untuk mengukur keberhasilan pembangunan pariwisata cenderung mengalami bias nilai dan bias kepentingan. Hal ini terjadi karena nilai-nilai yang dipakai bersumber dari pengalaman negara-negara maju yang secara historis dan kultural memiliki karakteristik yang berbeda dengan negara berkembang, dalam hal ini seperti Indonesia. Kondisi ini mengakibatkan terjadinya peminggiran dan hegemoni terhadap unsur-unsur lokalitas dalam pengelolaan destinasi pariwisata di Bali Utara. Menurut Prasiasa (2012), hegemoni dalam pengembangan pariwisata tidak saja berupa peminggiran terhadap unsur-unsur lokalitas, akan tetapi juga terjadi pada partisipasi masyarakat lokal dalam pengembangan pariwisata.

Berdasarkan uraian tersebut, permasalahan penelitian ini adalah bagaimanakah masyarakat Bali Utara (dari Timur yaitu kawasan Air Sanih sampai ke Barat yaitu kawasan Pemuteran) mempraktikkan nilai estetika lokal dan nilai ekonomi lokal dalam pengelolaan destinasi pariwisata, serta bagaimanakah model pengelolaan destinasi pariwisata Bali Utara yang berkembang hingga saat ini. Sedangkan tujuan dari penelitian ini adalah menemukan unsur-unsur penerapan nilai estetika lokal dan nilai ekonomi lokal yang ada di masyarakat Bali Utara dalam pengelolaan destinasi pariwisata, serta merumuskan model pengelolaan destinasi pariwisata Bali Utara berdasarkan nilai estetika dan nilai ekonomi lokal.

\section{KAJIAN PUSTAKA}

Untuk memahami lokalitas, diperlukan pemahaman tentang konteks kehidupan masyarakat, wilayah, dan tempat masyarakat berinteraksi dengan alam dan budaya. Menurut Poespoprodjo (1985), Friedman (1994), dan Sugiharto (1996) unsur lokalitas yang berupa nilai lokal merupakan keyakinan setempat, yang terungkap melalui refleksi internalisasi dari pola pikir, pola sikap, dan pola perilaku untuk berinteraksi dengan lingkungan dan tantangan setempat dalam kehidupan masyarakat setempat. Wujud dari nilai lokal adalah kearifan lokal, sedangkan identitas masyarakat setempat memiliki kekhasan budaya. Akibatnya, seringkali muncul tradisi baru dari interaksi masyarakat lokal dengan entitas lain. Melalui 
transformasi dan adaptasi, perlu dilakukan rekayasa secara positif dalam mengelola nilai-nilai lokal menjadi nilai yang bersifat progresif, guna mewujudkan aktivitas kepariwisataan yang lebih adil, bertanggungjawab dan berkelanjutan.

Estetika lokal selain terkait dengan keserasian dan keindahan dari wujud bangunan, juga terkait dengan perilaku yang dimiliki masyarakat lokal. Nilai estetika mengandung makna keserasian, harmonis dan kesesuaian dengan lingkungan masyarakat lokal (Sutrisno dan Christ, 1991). Ciri nilai estetika lokal dapat dilihat dari aktivitas menyimpan benda-benda sakral di gedong simpen, menggunakan busana adat pada saat upacara keagamaan, persembahan taritarian sakral dalam suatu upacara adar, menjadikan terasering sawah yang teratur sebagai sarana pengairan sawah, membangun rumah dengan ciri arsitektur khas desa setempat, serta penyelenggaraan festival kesenian dengan mengangkat seni dan budaya setempat.

Nilai ekonomi lokal memberikan manfaat ekonomi secara lokal. Manfaat ekonomi dapat berupa manfaat langsung dan manfaat tidak langsung, dapat berupa barang dan jasa sebagai hasil dari transaksi ekonomi. Selain itu, menurut Wall (1982) ekonomi lokal adalah kegiatan produksi, distribusi dan konsumsi masyarakat dengan kandungan lokal yang dilakukan dan dikendalikan oleh masyarakat secara langsung dan memberikan manfaat kepada daerah dan masyarakat lokal secara berkesinambungan.

Tantangan dari pengelolaan destinasi pariwisata pada masa mendatang serta dalam jangka panjang adalah perlunya memperhatikan fenomena pasar, perubahan lingkungan, dan manajemen pengelolaan yang bersumber dari unsur sumber daya dan kapasitas lokalitas (Susanto, 2010; Cooper, 2005). Pengelolaan destinasi pariwisata merupakan rangkaian aktivitas untuk meningkatkan kapasitas destinasi pariwisata melalui perencanaan yang komperehensif, implementasi perencanaan yang konsisten, serta pengendalian yang ketat untuk mengoptimalkan daya tarik wisata, aksessibilitas, infrastruktur serta partisipasi masyarakat untuk memperoleh manfaat dari aspek sosial budaya, lingkungan dan ekonomi.

\section{METODE PENELITIAN}

Kajian nilai estetika lokal dan nilai ekonomi lokal dalam pengelolaan destinasi pariwisata di Bali Utara menggunakan metode tinjauan pustaka berdasarkan analisis deskriptif kualitatif. Sebagai sebuah metodologi yang jarang diimplementasikan dalam suatu penelitian, menurut Snyder (2019), tinjauan pustaka dapat diperlakukan sebagai metodologi penelitian. Metode tinjauan pustaka juga dikenal sebagai metode literatur atau juga disebut sebagai Comprehensive Literature Review (Onwueg and Frels, 2016). Ini berarti metode tinjauan pustaka merupakan metodologi analisis teoretis yang mengkaji dan membahas materi secara teoretis dan deskriptif, dan dalam konteks tertentu dapat dilakukan perbandingan dengan sebuah konsep (Comerasamy, 2012). Adapun wilayah penelitian mencakup destinasi pariwisata di Bali Utara yang meliputi dari Timur yaitu kawasan Air Sanih sampai ke Barat yaitu kawasan Pemuteran.

\section{PEMBAHASAN}

\section{Nilai Estetika Lokal dan Nilai Ekonomi Lokal dalam Pengelolaan Destinasi Pariwisata di Bali Utara}

Dari aspek nilai estetika lokal, masyarakat Bali Utara sebagian besar masih patuh terhadap tradisi dan larangan yang ditetapkan desa adat dan oleh pemerintah daerah. Hal ini ditunjukkan dengan kepatuhan masyarakat untuk mengadakan upacara adat, melestarikan arsitektur lokal, digunakannya bahan-bahan lokal untuk pembangunan, dan mendukung upaya konservasi budaya yang dimilikinya sebagai warisan budaya. Timbulnya kesadaran masyarakat untuk menyelamatkan sumber daya budaya melalui penerapan arsitektur lokal dan penggunaan tradisi lokal merupakan pencerminan dari adanya kemampuan dari masyarakat lokal untuk terus menerapkan dan melestarikan kearifan lokal berupa nilai estetika lokal.

Nilai ekonomi lokal dalam konteks budaya antara lain perwujudannya dalam bentuk transaksi ekonomi yang tidak semata-mata bernilai uang, nilai sumber daya yang bukan berwujud uang, penggunaan bahan baku lokal pada usaha-usaha pariwisata yang ada di destinasi pariwisata, dan adanya modal kerja yang bersifat kolektif pada usaha-usaha pariwisata. Kekuatan ekonomi lokal di destinasi pariwisata dapat terbentuk dari proporsi modal kerja kolektif yang tumbuh di destinasi pariwisata Bali Utara. Adanya perkembangan destinasi pariwisata di Bali Utara telah menimbulkan praktik alih fungsi lahan serta penjualan tanah sepanjang garis pantai di Bali Utara. Praktik-praktik tersebut jelas bertentangan dengan ekspresi kepemilikan sumber daya yang akan diwariskan masyarakat kepada generasi mendatang. Meskipun demikian, masih terdapat praktik positif berupa terdapatnya kearifan lokal tentang relasi masyarakat dengan tanah sebagai bagian dari tri hita karana. Kearifan lokal dari sisi tri hita karana 
berimplikasi positif terhadap keterlibatan serta partisipasi masyarakat lokal dalam pengelolaan destinasi pariwisata di Bali Utara.

Adanya implementasi atau penerapan nilai-nilai lokal pada pengelolaan destinasi pariwisata di Bali Utara semakin memperjelas identitas serta karakteristik lokal bagi tumbuh dan berkembangnya destinasi pariwisata, khususnya dalam implementasi atau penerapan tatanan nilai lokal di destinasi pariwisata. Kebertahanan nilai lokal dalam pengelolaan destinasi pariwisata mengakibatkan terjaganya hak-hak lokal. Dalam konteks pengelolaan destinasi pariwisata, adanya nilai estetika lokal dan nilai ekonomi lokal dapat dijadikan salah satu alternatif atraksi wisata, sekaligus sebagai modal sosial yang dapat dijadikan magnet untuk menarik kunjungan wisatawan. Adapun penerapan nilai estetika lokal dan nilai ekonomi lokal dalam pengelolaan destinasi pariwisata di Bali Utara seperti Tabel 1.

Tabel 1. Penerapan Nilai Lokal Dalam Pengelolaan Destinasi Pariwisata Di Bali Utara

\begin{tabular}{|c|c|c|c|}
\hline No & Nilai & Lokal & Non-Lokal \\
\hline 1. & Estetika & $\begin{array}{lr}\text { Tradisi } & \text { Lokal, } \\
\text { Arsitektur Lokal, } \\
\text { Upacara } & \text { Lokal } \\
\text { dan } & \text { Busana } \\
\text { Lokal } & \end{array}$ & $\begin{array}{l}\text { Pengalaman } \\
\text { Estetis yang } \\
\text { bersifat Artifisial }\end{array}$ \\
\hline 2. & Ekonomi & $\begin{array}{l}\text { Lebih } \\
\text { menonjolkan } \\
\text { Sumber Daya } \\
\text { Budaya, tidak } \\
\text { bersifat material, } \\
\text { mengandung } \\
\text { kearifan lokal }\end{array}$ & $\begin{array}{l}\text { Komodifikasi, } \\
\text { komersialisasi, } \\
\text { hubungan didasari } \\
\text { oleh ekonomi, } \\
\text { banyak } \\
\text { mengandung } \\
\text { muatan dari luar } \\
\text { (non-local } \\
\text { content) }\end{array}$ \\
\hline
\end{tabular}

Sumber: Data Primer, 2021 (diolah)

Tabel 1 memperlihatkan bahwa nilai estetika dalam pengelolaan destinasi pariwisata di Bali Utara dapat disajikan melalui penampilan tradisi lokal, penggunaan arsitektur lokal, dan terselenggaranya upacara lokal dan busana lokal sebagai produk wisata yang disuguhkan kepada wisatawan. Nilai estetika lokal di Bali Utara dalam operasionalnya dihadapkan pada nilai estetika yang dibawa oleh wisatawan, baik melalui interaksi langsung maupun interaksi tidak langsung. Nilai estetika yang dibawa oleh wisatawan sebagai guest, memang terlihat bersifat estetis namun perwujudannya sangat bersifat artifisial. Menghadapi kondisi seperti tersebut, maka kebertahanan dari masyarakat Bali Utara sebagai pelaku pariwisata harus benar-benar memiliki pemahaman yang kuat terhadap nilai estetika lokal, sehingga tidak terpengaruh oleh nilai- nilai estetis artifisial yang dibawa oleh wisatawan, apalagi merubah estetika lokal menjadi estetis artifisial.

Pengalaman estetis artifisial artinya sebuah pengalaman yang bukan bersumber dari kandungan lokal dan menimbulkan benturan-benturan dengan estetika lokal. Estetika lokal banyak menyajikan praktek transaksi yang tidak semata-mata berdasarkan uang atau materi, melainkan sumber daya tidak dihitung dengan nilai nominal berupa uang, dan sangat memperhatikan dan menghargai kandungan lokal. Terkait dengan kandungan lokal, menurut Fulzi (2016) bentuk visual alam beserta seluruh peristiwa yang terjadi di sekitarnya dapat diserap secara terus menerus oleh para seniman tradisi, terakumulasi dalam alam bawah sadar dan akhirnya membentuk konsep estetika lokal tentang bunyi yang indah, yaitu bunyi yang berasal dari alam dan selaras dengan alam. Bunyi-bunyian yang membentuk hasil karya estetis tersebut merupakan karya seni yang dapat mendukung pengelolaan destinasi pariwisata, dan dapat dinikmati oleh wisatawan tanpa transaksional. Sebaliknya, arus globalisasi sebagai era postmodern telah mendorong secara kuat praktik-praktik atau hubungan yang bersifat transaksional ekonomis, semua produk budaya dianggap sebagai komoditi yang semuanya bisa dijual atau dikomersilkan (komodifikasi), berorientasi pada keuntungan ekonomis semata, dan produk-produk pariwisata sebagian besar didominasi oleh kandungan nonlokal.

Pada sisi lain, secara internal atau di kalangan masyarakat lokal Bali Utara, ditemukan kecenderungan yang cukup menonjol yaitu terjadinya pelemahan terhadap nilai-nilai lokal antara lain terjadinya ketidakkonsistenan atau inkonsistensi pada penerapan nilai-nilai lokal dalam kehidupan sehari-hari, tingkat kesadaran kritis masyarakat terhadap pelestarian nilai-nilai lokal yang masih ditentukan oleh tingkat pendidikan masyarakat lokal, dan tipologi masyarakat lokal yang sangat heterogen. Selain pengaruh internal, terdapat juga pengaruh eksternal yang cukup kuat, antara lain berupa kurangnya regulasi pemerintah daerah dalam mengatur nilai-nilai estetika lokal dn nilai-nilai ekonomi lokal, meningkatnya budaya konsumerisme di kalangan masyarakat lokal, dan pengaruh kemajuan teknologi informasi dan komunikasi (information and communication technology atau ICT). Hal ini sejalan dengan Maninggar dan Hudalah (2018) bahwa paradigma industri berbasis high-tech sangat potensial untuk menciptakan inovasi dan mendorong pembangunan dan akan merubah kebutuhan ekonomi lokal. 
Berkembangnya pengelolaan destinasi pariwisata di Bali Utara membawa dampak kepada masuknya muatan atau nilai-nilai yang dibawa oleh wisatawan. Selain menyerap nilai-nilai yang bersifat positif dari wisatawan, pada saat yang sama masyarakat lokal juga akan menerima atau mulai mengalami dampak atau ekses negatif dari kegiatan kepariwisataan. Masyarakat Bali Utara akan menerima nilai-nilai yang dibawa oleh wisatawan antara lain terkait dengan ketersediaan rencana bisnis, ketersediaan jaminan mutu produk pariwisata, dan tingkat penyesuaian diri terhadap budaya persaingan. Nilainilai yang dibawa oleh wisatawan terbukti mempengaruhi kualitas pengelolaan destinasi pariwisata di Bali Utara.

Dalam perkembangannya, nilai-nilai yang dibawa oleh wisatawan memperoleh respons relatif positif dari masyarakat terutama terkait perencanaan bisnis, standar jaminan mutu produk pariwisata, dan kesiapan atau tingkat penyesuaian terhadap budaya persaingan. Meskipun beberapa nilai yang dibawa oleh wisatawan telah mampu diterima oleh masyarakat lokal, namun berbagai ancaman dari luar terhadap perilaku bisnis pariwisata mulai tumbuh. Berbagai ancaman dari luar terhadap perilaku bisnis pariwisata antara lain modal finansial dikendalikan oleh pelaku pariwisata dari luar dan didukung oleh kompetensi dan jaringan. Hal ini dapat terjadi karena hingga saat ini belum adanya peraturan yang ketat dan jelas terhadap implementasi partisipasi masyarakat lokal berbasis nilai lokal dalam pengelolaan destinasi pariwisata. Peraturan ini diperlukan untuk menjaga kapasitas masyarakat lokal dalam pengelolaan destinasi pariwisata, sehingga terjadi kondisi seimbang dalam praktik penyelenggaraan kepariwisataan.

Hasil penelitian ini menunjukkan bahwa penerapan nilai ekonomi lokal terhadap keberhasilan pengelolaan destinasi pariwisata di Bali Utara sangat dipengaruhi oleh kebijakan pemerintah, investasi, kapasitas sumber daya manusia, dan kemampuan finansial. Ini berarti nilai ekonomi lokal berpengaruh terhadap keberhasilan pengelolaan destinasi pariwisata di Bali Utara, meskipun tidak berpengaruh dominan. Hal ini disebabkan karena pemahaman masyarakat terhadap praktik penerapan ekonomi lokal masih mengalami berbagai tantangan, terutama karena kehadiran praktik ekonomi yang lebih berorientasi ekonomi modern. Meskipun nilai ekonomi lokal belum berpengaruh dominan terhadap kesuksesan pengelolaan destinasi pariwisata di Bali Utara, namun temuan ini menunjukkan bahwa masyarakat telah mengalami benturan nilai. Praktik penerapan transaksi tanpa nilai tukar uang, permodalan kolektif, dan penggunaan bahan baku lokal dapat diperkuat melalui berbagai intervensi oleh pemerintah. Kebijakan yang prolokal dengan dukungan nilai estetika yang baik akan mendorong kontribusi nilai lokal terhadap penguatan kedaulatan ekonomi lokal.

Selain itu, nilai estetika lokal juga berpengaruh terhadap kesuksesan pengelolaan destinasi pariwisata di Bali Utara. Berbagai indikator dalam nilai estetika lokal, seperti kepatuhan pada aturan atau awig-awig yang dibuat desa adat, kebertahanan aristektur bangunan lokal, ketaatan untuk melaksanakan upacara adat dengan kearifan lokal, serta kegiatan konservasi sumber daya alam dan budaya perlu terus dilakukan agar nilai estetika lokal dapat berkontribusi optimal terhadap pengelolaan destinasi pariwisata di Bali Utara. Hal ini sejalan dengan Purnomo et.al (2020) yang menyatakan bahwa kekayaan budaya dan kearifan lokal dapat terus digali dan dikembangan.

\section{Model Pengelolaan Destinasi Pariwisata di Bali Utara}

Pengelolaan destinasi pariwisata menganut prinsif keseimbangan sebagai akibat adanya nilai lokal dan nilai nonlokal, harus mampu menerapkan nilai estetika. Keberhasilan serta keberlanjutan pengelolaan destinasi pariwisata akan ditentukan oleh kualitas penerapan nilai-nilai lokal. Oleh karena itu pengelolaan destinasi pariwisata perlu memasukkan nilai estetika lokal dan nilai ekonomi lokal yang telah disesuaikan dengan tatanan nilai kekinian, agar tercipta keseimbangan nilai. Salah satu kunci sukses dalam pengelolaan destinasi pariwisata ke depan adalah terletak pada kemampuan pengelola dalam menjaga keseimbangan antara nilai estetika lokal dengan nilai ekonomi lokal.

Dalam persektif yang lebih komprehensif, kesuksesan pengelolaan destinasi pariwisata akan banyak ditentukan oleh faktor internal dan eksternal. Dalam penelitian ini, pengelolaan destinasi pariwisata terbentuk dari perencanaan dan implementasi program, daya dukung sosial, dan daya dukung fisik (Inskeep, 1995; Page, 2007; Cooper et.al, 2005), infrastruktur dan fasilitas pariwisata, mutu pelayanan yang sesuai dengan preferensi dan motivasi pasar (Ross, 1998) dan partisipasi masyarakat melalui penerapan keseimbangan nilai estetika dan ekonomi lokal.

Kualitas pengelolaan destinasi pariwisata ditentukan melalui penerapan pola yang sistematis, sehingga tercipta keseimbangan yang sistemik untuk mengelola setiap bagian melalui komunikasi yang terpadu dengan semua komponen usaha pada 
destinasi pariwisata. Hal ini dilakukan melalui peningkatan akuntabilitas pengelolaan destinasi pariwisata serta partisipasi masyarakat lokal dalam rangka berinteraksi dengan masyarakat lain (Boissevain, 1972; Garna 1999). Untuk itulah diperlukan manajemen yang terintegrasi dalam pengelolaan destinasi pariwisata melalui tahapan peningkatan kesadaran kolektif pemangku kepentingan, implementasi manajemen dalam pengelolaan destinasi pariwisata, pengembangan usaha pariwisata yang sesuai dengan karakteristik destinasi pariwisata, dan penguatan kelembagaan dalam pengelolaan destinasi pariwisata.

Sistem pengelolaan destinasi pariwisata dengan melibatkan pemangku kepentingan dapat dilakukan melalui penguatan relasi yang bersifat transaksional, dengan tujuan untuk membentuk kualitas relasi antara masyarakat setempat dengan wisatawan, membuat database, marketing, danvisitors information dan manajemen. Dengan demikian, diperlukan tingkat sosial carrying capacity, kualitas relasi, dan ketepatan penerapan nilai di suatu destinasi pariwisata. Tindakan antisipatif dan proaktif untuk meningkatkan kualitas kepariwisataan yang berkelanjutan, bertanggung jawab, dan berkeseimbangan dilakukan dengan mereduksi kepentingan dan hegemoni yang ada dan berkembang di destinasi pariwisata.

Optimalisasi kontribusi nilai lokal dan penerapan nilai nonlokal untuk mencapai keberhasilan dalam pengelolaan destinasi pariwisata ditentukan oleh peningkatan kedudukan ekonomi masyarakat, pemasaran dan promosi, pengembangan produk dan pelayanan, kualitas pengalaman wisata, dan relasi pemangku kebijakan, yang didukung oleh penguatan kelembagaan destinasi pariwisata melalui aktivitas operasional, sumber daya keuangan dan manusia, dan pengukuran kinerja (Bornhorst et.al, 2010). Ini berarti keberhasilan dalam pengelolaan destinasi pariwisata merupakan kristalisasi dari kekuatan pengelolaan seeara internal dengan dukungan keuangan dan sumber daya manusia yang profesional, kerjasama dan kemitraan dengan pemangku kepentingan, partisipasi masyarakat lokal, dan kemampuan dalam menciptakan kualitas pengalaman berkunjung bagi wisatawan.

Konfigurasi model pengelolaan destinasi pariwisata secara makro diarahkan untuk menciptakan model yang berisi nilai-nilai dasar untuk dapat dikembangkan melalui koordinasi, interkoneksiantara pemangku kepentingan, kepemimpinan, dan akuntabilitas. Hal itu dikembangkan dalam rangka mengimplementasikan pola pengelolaan destinasi pariwisata yang mempertimbangkan pendekatan manajemen bisnis untuk meningkatkan kepuasan wisatawan dan kepuasan masyarakat lokal. Kapasitas destinasi pariwisata diciptakan melalui perencanaan yang komprehensif, implementasi yang konsisten dan kontrol yang tepat untuk optimasi kapasitas daya tarik, aksessibilitas, fasilitas, dan masyarakat dalam pencapaian manfaat secara ekologis, sosial dan ekonomis. Pengelolaan berbasis nilai ditujukan untuk mengelola sumber daya secara cerdas agar dapat memberi manfaat kepada masyarakat.

Pengelolaan destinasi pariwisata melalui pendekatan tripple bottom line ditujukan untuk mengelola relasi asimetris dan memperkuat kompetensi pemangku kepentingan untuk saling berdialog agar mampu meningkatkan keunggulan lokal dalam persaingan global. Keunggulan lokal dari destinasi pariwisata Bali Utara (Air Sanih hingga Pemuteran) terbentuk dari kandungan nilai estetika dan didukung oleh nilai etis yang diwujudkan dalam bentuk penerapan nilai keramahtamahan, musyawarah desa adat, keputusan desa adat, rasa hormat kepada tokoh masyarakat dan kebersamaan. Nilai estetika mencakup upaya konservasi lingkungan untuk menjaga keserasian alam dan arsitektur lokal dengan dukungan teknologi lokal. Sedangkan kandungan ekonomi lokal terdiri dari tradisi transaksional non tunai dari produk yang memiliki kandungan lokal. Pengelolaan destinasi pariwisata diarahkan untuk mengoptimalkan peran dan fungsi pemangku kepentingan (pemerintah, sektor swasta dan kelompok masyarakat) dalam kegiatan keparwisataan di Bali Utara.

Dengan model pengelolaan seperti ini, maka diperlukan pusat distribusi wisatawan untuk menghubungkan dan memperkuat keterlibatan masyarakat pesisir di Bali Utara, masyarakat di sekitar perbukitan, tokoh masyarakat, pemerintah daerah, dunia usaha, dan pelaku pariwisata. Pengelolaan destinasi pariwisata Bali Utara harus terkait dengan pengelolaan Taman Nasional Bali Barat, dan memperhatikan kelestarian dan kekayaan ekosistem bawah laut. Keterlibatan pemangku kepentingan perlu dirancang secara sistemik dalam proses manajerial dengan format keseimbangan dan penciptaan manfaat bidang pariwisata bagi masyarakat.

Model kesuksesan pengelolaan destinasi pariwisata di Bali Utara dapat dikembangkan melalui koordinasi, interkoneksi antara pemangku kepentingan, kepemimpinan, akuntabilitas dalam rangka menerapkan pola pengelolaan destinasi pariwisata yang mempergunakan pendekatan 
manajemen bisnis untuk meningkatkan kepuasan wisatawan dan kepuasan masyarakat. Optimalisasi daya tarik wisata, aksessibilitas, fasilitas, dan masyarakat perlu dikelola untuk menciptakan penguatan manfaat seeara ekologis, sosial dan ekonomis. Pengelolaan berbasis nilai (value-based management) ditujukan untuk mengadopsi sumber daya secara cerdas sehingga terkait satu dengan yang lainnya guna meningkatan kapasitas kegiatan ekonomi, masyarakat dan lingkungan.

Temuan dari penelitian ini adalah sebagai berikut. Lokalitas merupakan raison d'etre kegiatan pengelolaan destinasi pariwisata di Bali Utara. Dengan kemampuan dari nilai lokal yang dimiliki, merupakan releksi dari adanya kekuatan untuk menjaga keseimbangan antar nilai estetika dan nilai ekonomi lokal. Nilai lokal yang ada belum secara optimal mampu menciptakan keseimbangan, sehingga berimplikasi pada rendahnya kontribusi nilai lokalitas terhadap keberhasilan pengelolaan destinasi pariwisata sebagai akibat kemampuan komunitas lokal yang masih rendah. Menurut Prasiasa dan Widari (2021) jika aktivitas ekonomi semakin berkembang dan menjadi dominan, maka akan terjadi komodifikasi terhadap produk wisata, yang pada akhirnya akan berimplikasi pada nilainilai yang ditampilkan oleh produk wisata.

Peningkatan kontribusi nilai estetika dan nilai ekonomi lokal diperlukan guna memenuhi kepuasan masyarakat dan kepuasan wisatawan. Dalam perspektif masyarakat tradisional, secara proporsional nilai lokal bersifat otonom, namun ketika terjadi relasi dan pertukaran nilai maka secara otomotis nilai-nilai tersebut berinteraksi dan mengakibatkan terjadinya pergeseran dan perubahan tatanan nilai lokal mengikuti dinamika dan pengaruh dari nilai-nilai dari luar yang dibawa oleh wisatawan.

Penerapan nilai estetika lokal dan nilai ekonomi lokal bersifat positif untuk peningkatan kontribusi pariwisata pada tatanan lokal, meskipun juga disadari bahwa nilai-nilai yang dibawa oleh wisatawan tidak selalu bersifat negatif jika pengelolaannya dilakukan mengikuti kaidah-kaidah kearifan lokal. Harus disadari bahwa aktivitas kepariwisataan saat ini didominasi oleh kapitalisme, yang berusaha lebih memperhatikan dan menonjolkan kepentingan untuk mempertahankan dan mengembangkan prinsip-prinsip ekonomi. Nilai-nilai yang dibawa oleh wisatawan tetap berpotensi untuk meniadakan peran dan kontribusi lokalitas, karena kecenderungannya untuk melakukan hegemoni terhadap nilai-nilai lokal yang sudah menjadi best-practices dalam pengelolaan destinasi pariwisata, dan bahkan tidak mempertimbangkan berbagai inisiatif dan inspirasi lokal yang seharusnya lebih diutamakan untuk implementasi nilai-nilai lokal. Temuan ini menegaskan kembali bahwa telah terjadi konflik antara nilai estetika lokal dan nilai ekonomi lokal terhadap nilai-nilai yang dibawa oleh wisatawan. Lebih lanjut menurut Prasiasa (2012), hegemoni pada nilai-nilai lokal akan dapat menyebabkan komodifikasi serta menghambat partisipasi masyarakat terhadap pengembangan pariwisata.

Konflik nilai estetika lokal dan nilai ekonomi lokal dengan nilai-nilai yang dibawa oleh wisatawan tidak langsung menimbulkan hibridisasi atau perkawinan antar nilai, namun masih melalui proses adaptasi, adopsi dan kooptasi. Hal ini dapat dilihat dari masih kuatnya unsur lokalitas dalam pengelolaan destinasi pariwisata di Bali Utara. Secara konkrit penerapan nilai lokal dapat dilihat dari masyarakat lokal memiliki nilai estetika dan nilai ekonomi lokal yang masih kuat yang bersifat positif dan dominan; pemahaman tentang esensi konservasi pada masyarakat lokal berbeda dengan pemahaman konservasi menurut kepentingan wisatawan, karena masyarakat Bali Utara memiliki kearifan secara khas dalam memanfaatkan sumber daya alam; kekuatan lokal dapat menciptakan kedaulatan lokal yang bermanfaat untuk membedakan seeara kritis dampak positif dan negatif terhadap nilai-nilai yang dibawa oleh wisatawan. Selain itu, nilai-nilai yang dibawa oleh wisatawan masih belum dominan sebagai akibat kuatnya nilai-nilai lokal yang berkembang di destinasi pariwisata Bali Utara. Kondisi ini memungkinkan nilai lokal memperoleh kesempatan (opportunity sets) untuk dikelola secara baik, sehingga memperkokoh kontribusi nilai estetika dan nilai ekonomi lokal dalam pengelolaan destinasi pariwisata di Bali Utara berbasis kearifan lokal. Hal ini sejalan dengan La Taena (2011) yang menyatakan bahwa kearifan lokal termasuk didalamnya pengetahuan lokal dan keahlian merupakan elemen dari penciptaan hubungan dan koordinasi dari dan antar komunitas lokal.

Dalam pengelolaan destinasi pariwisata di Bali Utara perlu menerapkan triangulasi lokal dengan format konvergensi, koordinasi, kepemimpinan, akuntabilitas dan kebijakan afirmatif dengan dukungan kesadaran kritis masyarakat untuk mendorong transformasi dan adopsi nilai intrinsik yang determinan menuju pengelolaan destinasi pariwisata yang baik. Pendekatan kerangka tripple bottom line dan inspirasi unsur lokalitas dapat diwujudkan melalui kandungan filosofis lokal dalam setiap produk yang disajikan di destinasi pariwisata. 


\section{SIMPULAN}

Unsur lokalitas dalam pengelolaan destinasi pariwisata di Bali Utara terbentuk dari perwujudan nilai estetika dan nilai ekonomi lokal yang diyakini sebagai kearifan lokal masyarakat, dan kedua nilai ini bersifat dominan. Kekuatan nilai lokal diperlukan dalam pengembangan destinasi pariwisata, agar tercipta keberlanjutan bagi budaya, masyarakat dan lingkungan. Sebagai sebuah local wisdom, nilai-nilai lokal berpotensi untuk meningkatkan keunikan dan kekhasan dari sumber daya sosial yang dimiliki masyarakat untuk dapat berkontribusi dalam pembangunan kepariwisataan di Bali Utara.

Ni1ai-nilai yang dibawa oleh wisatawan dapat berimplikasi positif (tonic) dan negatif (toxic), sekaligus menjadi penggerak perubaan nilai bagi masyarakat lokal dengan ekses positif dan negatif. Respons masyarakat terhadap nilai-nilai yang dibawa oleh wisatawan dapat dilihat dari adanya transformasi nilai-nilai dalam pengelolaan destinasi pariwisata, yang ditandai dengan terjadinya fenomena negatif seperti adanya pergeseran nilai lokal pada aktivitas yang dilakukan oleh masyarakat untuk memenuhi kebutuhan wisatawan.

Kontribusi nilai estetika lokal dan nilai ekonomi lokal terhadap nilai-nilai yang dibawa oleh wisatawan belum optimal dalam pengelolaan destinasi pariwisata di Bali Utara. Kesuksesan pengelolaan destinasi pariwisata akan terbentuk melalui perencanaan dan implementasi program, daya dukung sosial, daya dukung fisik, peningkatan infrastruktur dan fasilitas pariwisata, peningkatan mutu pelayanan yang disesuaikan dengan preferensi dan motivasi wisatawan serta didukung oleh partisipasi masyarakat.

\section{DAFTAR RUJUKAN}

Boissevain, J. 1972. Network Analysis Studies in Human Interaction. Paris: Mouton \& Co

Bornhorst T., Ritchie, B.J.R, and Steehan, L. 2010. Determinants of Tourism Success for DMOS \& Destinations: An Empirical Examination of Stakeholders' Perspectives. Journal Tourism Management, $\quad 51(31), \quad$ 572-589. https://doi.org/10.1016/j.tourman.2009.06.008

Carter, R., Fabricius, M. 2006. Destination Management an Overwiew, In UNWTO: Creating Competitive Advantage for your Destination. Budapest, 7 Pebruari 2007
Comerasamy, H. 2012. Literature based Research Methodology. UK

Cooper, C., Fletcher, J., Gilbert, D., Wanhill, S. 2005. Tourism Principle and Practices. London: Pitman Publishing

Fulzi, N. 2016. Alam dan Adat Sebagai Sumber Estetika Lokal Kesenian Talempong Lagu Dendang. EKSPRESI SENI Jurnal Ilmu Pengetahuan dan Karya Seni, 18(1), Juni 2016, 164-179

Friedman, J. 1994. Indigenious Struggles and the Discreet Charm of the Bourgeoisie. Journal of World System Research, 2, 391-413

Garna, Y. 1999. Teori Sosial dan Pembangunan Indonesia: Suatu Kajian Melalui Diskusi. Bandung: Primaco Academica

Inskeep, E. 1995. Tourism Planning an Integrated and Sustainable Development Approach. New York: Van Nostrand Reinhold

La Taena. 2011. Analysis of the Bajau People's Local Genius as the Cathalist for Empowering Community in the Perspective of Cultural Studies. MUDRA Journal of Art and Culture, 26(3), December 2011, 253-259

Maninggar, N., Hudalah, D. 2018. Low-tech Innovation and Local Economic Development: Case Study The Traditional Batik Industry in Pekalongan Municipality. Jurnal Tata Loka, 20(1), Pebruari 2018, 1-11

Onwueg, A. J., \& Frels, R. 2016. Methodology of the Literature Review. In Seven Steps to a Comprehensive Literature Review; A Multimodal \& Cultural Approach. London: Sage Publication Ltd

Page, S.J. 2007. Sustainable Tourism. London: Routledge

Poespoprodjo, W. 1985. Filsafat Moral, Kesusilaan dalam Teori dan Praktik. Bandung: Remadja Karya

Purnomo, A.D., Amelia, K.P., Dirayati, S. 2020. Penerapan Elemen Estetik Sebagai Identitas Budaya Lokal Pada Elemen Interior Terminal Penumpang BIJB Kertajati. WACA CIPTA RUANG Jurnal Ilmiah Desain Interior, 6(1), 19-24

Prasiasa, D.P.O. 2012. Hegemoni Pengembangan Pariwisata dan Keterlibatan Masyarakat di Desa Wisata. MUDRA Jurnal Seni Budaya, 27(1), Januari 2012, 62-77 
Prasiasa, D. P. O., \& Diyah Sri Widari, D. A. . (2021). Kajian Estetika Postmodern Terasering Sawah Di Desa Wisata Jatiluwih Sebagai Daya Tarik Wisata. Mudra Jurnal Seni Budaya, 36(3), 375-385.

https://doi.org/10.31091/mudra.v36i3.1405

Ross. 1998. Psychology of Tourism. New York: Prentice Hall

Sugiharto, B.I. 1996. Postmodernisme. Yogyakarta: Kanisius

Susanto, A.B. 2010. Pendekatan Manajemen Modern. Jakarta: Ghalia

Sutrisno, M., Christ, V. 1991. Estetika Filsafat Keindahan. Yogyakarta: Kanisius

Snyder, H., 2019. Literature Review as a Research Methodology: An Overview and Guidelines. Journal of Business Research, 104, 333-339

Wall. G. 1982. Tourism Management. Waterloo University Canada 